\title{
Segmentation of coastal marine demand from a National Recreational Area: Villamil Beach, Ecuador
}

\author{
Mauricio Carvache-Franco ${ }^{A}$, Orly Carvache-Franco ${ }^{\mathrm{B}}$, Wilmer Carvache-Franco ${ }^{C^{*}}$, \\ Miguel Orden-Mejía ${ }^{\mathrm{D}}$, Cristina Macas-López ${ }^{\mathrm{E}}$ \\ Received: July 26, 2018 | Revised: December 05, 2018 | Accepted: December 10, 2018
}

DOI: $10.5937 / g p 22-18410$

\begin{abstract}
Tourist demand segmentation can provide important information for creating products tailored to the clusters found. The present empirical work was carried out in situ in Ecuador at the Villamil Beach National Recreation Area, a coastal marine destination within a national recreation area. Factor analysis on responses by tourists to a questionnaire produces two motivational dimensions: "Ecotourism" and "Sun and beach". Three tourist segments are found: "Beach lovers", who have high motivations for enjoying the sun and the beach, "Coastal Nature", who have high motivations for enjoying the typical gastronomy, for the sun and the beach, for the tourist attractions and for knowing the flora and fauna and, finally, "Coastal Passive", who have medium and low motivations in all aspects.
\end{abstract}

Keywords: Tourism; Segmentation; Motivation; Coastal marine; Ecuador

\section{Introduction}

In January 2018, the Barometer of the World Tourism Organization (UNWTO) reported a global total of 1,322 million tourist arrivals in 2017 , some 83 million more than 2016. This remarkable increase of $7 \%$ is substantially higher than the sustained rate of $4 \%$ registered since 2010 and represents the highest increase in seven years. The Americas ( $+3 \%$ overall) received 207 million tourists, and South America led the regional growth with a $7 \%$ increase. According to their Ministry of Tourism (MINTUR, 2018) Ecuador had an arrival increase of $14 \%$. Their arrival numbers were $1,617,914$ which generated a weight of tourist consump- tion of $1.7 \%$ in the Gross Domestic Product (GDP). Finally, WTO experts predict that arrivals will grow at a rate between $4 \%$ and $5 \%$ in 2018.

"Sun and beach" tourism has been an important component of worldwide demand in recent years, based mainly on the preference of Asian and American markets, with a growth of $6 \%$ in 2016 and 9\% in 2017 (ITB World Travel Trends Report 2017/2018). This recreational use of the coast and the sea seems destined to increase in the coming years (Orams \& Lück, 2013). In this context, coastal locations are, broadly speaking, defined as those areas that are adjacent to

\footnotetext{
A Universidad Espíritu Santo-Ecuador; mauricio2714@hotmail.com

B Universidad Católica de Santiago de Guayaquil. Facultad de Especialidades Empresariales, K 1.5, Av. Carlos Julio Arosemena, Guayaquil, Ecuador; orly.carvache@cu.ucsg.edu.ec

c Escuela Superior Politécnica del Litoral, ESPOL, Facultad de Ciencias Sociales y Humanísticas, Campus Gustavo Galindo Km 30.5 Vía Perimetral, P.O. Box 09-01-5863, Guayaquil, Ecuador. Universitat Rovira i Virgili, Spain; wcarvach@espol.edu.ec

D Universitat Rovira i Virgili, Spain; miguelorden@gmail.com

E Universidad de Guayaquil. Facultad de Ingeniería Química, Guayaquil, Ecuador; cristina.macasl@ug.edu.ec

* Corresponding author: Wilmer Carvache-Franco; e-mail: wcarvach@espol.edu.ec
} 
the sea (Beatley et al., 2002). The coastal zone extends inland to the first major change in topography beyond which coastal processes have little influence. (International Coastal and Marine Tourism Society, 2013). Marine Tourism includes those recreational activities that involve travelling a significant distance from the visitor's place of residence and for which the marine environment acts as a host or focus (Orams, 1999, p.9). It now extends beyond beach-based activities to include a wide spectrum of activities, which include scuba-diving and snorkelling, windsurfing, jet skiing, fishing, sea kayaking, visits to fishing villages, marine parks and aquariums, sailing and motor yachting, maritime events and races, as well as the cruise ship industry (Lück, 2007). Coastal tourism currently includes a wide variety of activities: sports (beach volleyball, coasteering, surfing, kayaking), wellness stays (spa and wellness resorts, beach walking, and beachcombing), nature based and wildlife viewing (rockpools, seabirds, turtles, pinnipeds), and volunteer and educational activities (beach clean-ups, invasive weed eradication, species counts, language schools, museums) (Orams \& Lück, 2016).

In Ecuador there are 51 natural reserves covering almost $20 \%$ of the national territory. Villamil city is located in the province of Guayas and the Ecuadorean Ministry of the Environment (MAE, 2012) has designated the Villamil Beach National Recreation Area (VBNRA) as Villamil city beach, extending for $14 \mathrm{Km}$ to the town of Data de Posorja. Due to its natural and cultural wealth, VBNRA is one of the main tourist destinations in the central coast of Ecuador, hosting some 1.25 million local and foreign tourists every year (MAE, 2015).

In Article 397(4), the constitution of the Republic of Ecuador 2008 affirms that the management and administration of protected natural areas is a State responsibility and commits itself: "To ensure the intangibility of the protected natural areas, in such a way that the conservation of biodiversity and the maintenance of the ecological functions of ecosystems are guaranteed". Through the National System of Protected Areas (NSPA), MAE ensures the coverage and connectivity of terrestrial, marine and coastal ecosystems, as well as their cultural resources and water sources (MAE, 2017). There are eight categories of protected areas and, due to the varied recreational services it offers, VBNRA is classed as a Natural Recreation Area (MAE, 2017).

Studies are increasingly important in relation to coastal marine destinations, especially in areas requiring environmental protection. However, no studies have yet profiled tourists visiting VBNRA and, consequently, segmentation of tourism demand has not been addressed. The current article presents the results of fieldwork addressing market segmentation in a National Recreation Area with a coastal marine tourism, for the benefit of conservation and the sustainable use of the area's resources.

\section{Theoretical framework}

It is important to address motivational aspects of demand segmentation. Thus, for Martínez, 2001; Rivas, 2004; Bigné et al. (2007), given that it is included in leisure tourism, the main motivation of the sun and beach tourist is rest and recreation. Morante et al., (2007) concur and see this as followed by fun and entertainment. For Carvache-Franco et al. (2018) the main motivations are to enjoy typical gastronomy, sun and beach, to rest and to visit its tourist attractions. In another study, Prebensen et al. (2010) use two motivational dimensions in sun and beach destinations, namely, Body-related (Sun and warmth, Fitness and health) and Mindrelated (Culture and nature, Escapism).

Regarding the findings for coastal marine destinations, for Molera and Abaladejo (2007) identified five reasons for traveling to Murcia (Spain), nature and tranquillity, physical and cultural activities, family, travel characteristics and rural life. In another study, Saayman et al. (2009) found five travel motivation factors for marine destinations in South Africa: escape and relaxation, destination attractiveness, socialization, personal attachment, site attributes and trip fea- tures. Kruger and Saayman (2010), studying tourists visiting Tsitsikamma National Park, located on the Indian Ocean in South Africa, found knowledge seeking, nature experience, photography, escape and relaxation, park attributes and nostalgia as reasons to travel. Van Der Merwe et al. (2011) found four motivational factors for coastal marine destinations: destination attractiveness, escape and relaxation, time utilization and personal attachment. In a study of several coastal areas in Africa, De Nisco et al. (2015) identified both common and site-specific motivations: common motivations were escape and relaxation, destination attractiveness, overall site attractiveness, and personal attachment. Additional specific motivations were leisure activities and novelty for Jeffreys Bay, and socialization and trip features for Hartenbos.

With respect to demand segmentation, for Woodside and Martin (2008) it offers a competitive advantage to the user, since the process helps in the efficient use of resources by not wasting them in trying to reach every aspect of the market with no clear objective. For Ho et al. (2012), market segmentation represents the 
decisive criterion for determining which customer groups should be addressed and how to use resources more effectively and evaluate different competitive strategies efficiently. Regarding this issue, Middleton et al. (2009) point out the four most commonly used criteria of segmentation: demographic, geographical, behavioural and psychographic. It is also important to keep in mind that the people marketing a destination's tourism services must understand visitor needs and desires when managing its resources and attempting to attract different groups of tourists (Pesonen, 2012). The more information available on the market and its component segments, the easier it is to design products or services that satisfy customers (Pulido-Fernández \& Sánchez-Rivero, 2010).

There is a considerable literature on the segmentation of demand in coastal marine tourists. Moscardo et al. (2000) in a study on three European tourist destinations identified three segments, Eco-coastal, Active Beach, and Passive Seaside tourists. The first group was characterised by the high scores given to activities, such as increasing contact with and knowledge of the natural environment, looking for cultural experiences and those aspects related to ethnic tourism, as well as to activities and experiences in national parks, forests, lakes, rivers and mountains. In a study by Garcia and Gallard (2002), concerned with segmentation according to environmental preferences, they found five segments: Unsatisfied, Elderly travellers, satisfied who return, Beach lovers, and Tranquillity lovers. In Spanish tourist demand segmentation Gonzáles and Molina (2007) found four clear segments: Tourism of average and long distance, interior family tourism, active coastal tourism, family tourism of sun and beach. On the other hand, Ferreira Lopes et al. (2010) when studying the same topic, established five clusters: Culture Seekers, Culture Seekers motivated by Low Prices, Sun and Tranquillity Seekers, Sun and Night Lovers, Night Lovers motivated by Low Prices.

On the other hand, Onofri and Nunes (2013), in a worldwide coastal marine study, found two tourist segments: Greens, tourists who choose their coastal destination because they have a strong preference for cultural and natural environments, and beach lov- ers who have a high preference for the beach. Within this framework, a study by Srihadi et al. (2016) identifies four segments: Culture interest shopaholic, represents foreign visitors who are interested in exploring different cultures and experiencing the local way of life. Sporty culture explorers, who enjoy meeting new people, and like spending time with their friends. People belonging to the Aspiring vacationer visitors segment have little interest in shopping for products when traveling abroad and have little interest in doing outdoor sport activities while traveling. Wanteverything vacationers have a high enthusiasm for exploring different cultures. Lee et al. (2018) suggest that tourists can be divided into four groups according to their recreational experiences: Multi-experience recreationists had the highest scores on all factors; Aestheticists had higher factor scores for experiential aesthetics and the lowest scores for experiential learning; Hedonists registered the lowest scores in experiential aesthetics and reflective factors and knowledge seekers had greater experiential aesthetics and learning factor scores. Using a method based on ontology, Valls et al. (2018) found the following groups: Visiting, who are motivated by access to culture, sightseeing, shopping, culture and well-being; Enjoying, who value the holidays, kindness, kindness, relaxation and entertainment; Holidaying, motivated by vacations on the beach and the holiday destination; Beaching, whose main factor is the beach; Sunbathing, whose main factors are holidays, the beach and the sun and Relaxing who are motivated by the beach and differ from previous groups in that the meaning of destiny is associated with the beauty of the place and the landscape, well-being and relaxation. A recent study (CarvacheFranco et al., 2019) argues for four segments in coastal marine destinations: Eco-coastal, who visit the destination motivated by climate, sand and contact with nature; Indifferent, with low scores in almost all motivation criteria and who are not clearly related to any of the three dimensions identified; Water Sports, who visit the destination motivated by surfing and who enjoy the sun and the beach and Sun and Beach, who visit the destination and are mainly motivated by rest and relaxation together with sun and beach criteria.

\section{Study of the area}

In the coastal region of Ecuador, the province of Guayas is made up of 25 cantons, one of which is General Villamil Playas, where the Villamil Beach National Recreation Area (VBNRA) is located. It is one of the NSPAs most visited by tourists, whose main attraction is its tranquillity; it is ideal for relaxing, walking, bird watching and water sports and is an important marine habitat. Located at 2.6333 South Latitude and 80.3833 West longitude, $80 \%$ of the land is flat the other $20 \%$ being low altitude hills. Studies conducted by UNESCO have shown that the area has the second-best climate in the world (Territorial Development and Planning Playas Villamil, 2014). From a cultural perspective, beached balsas (tradi- 


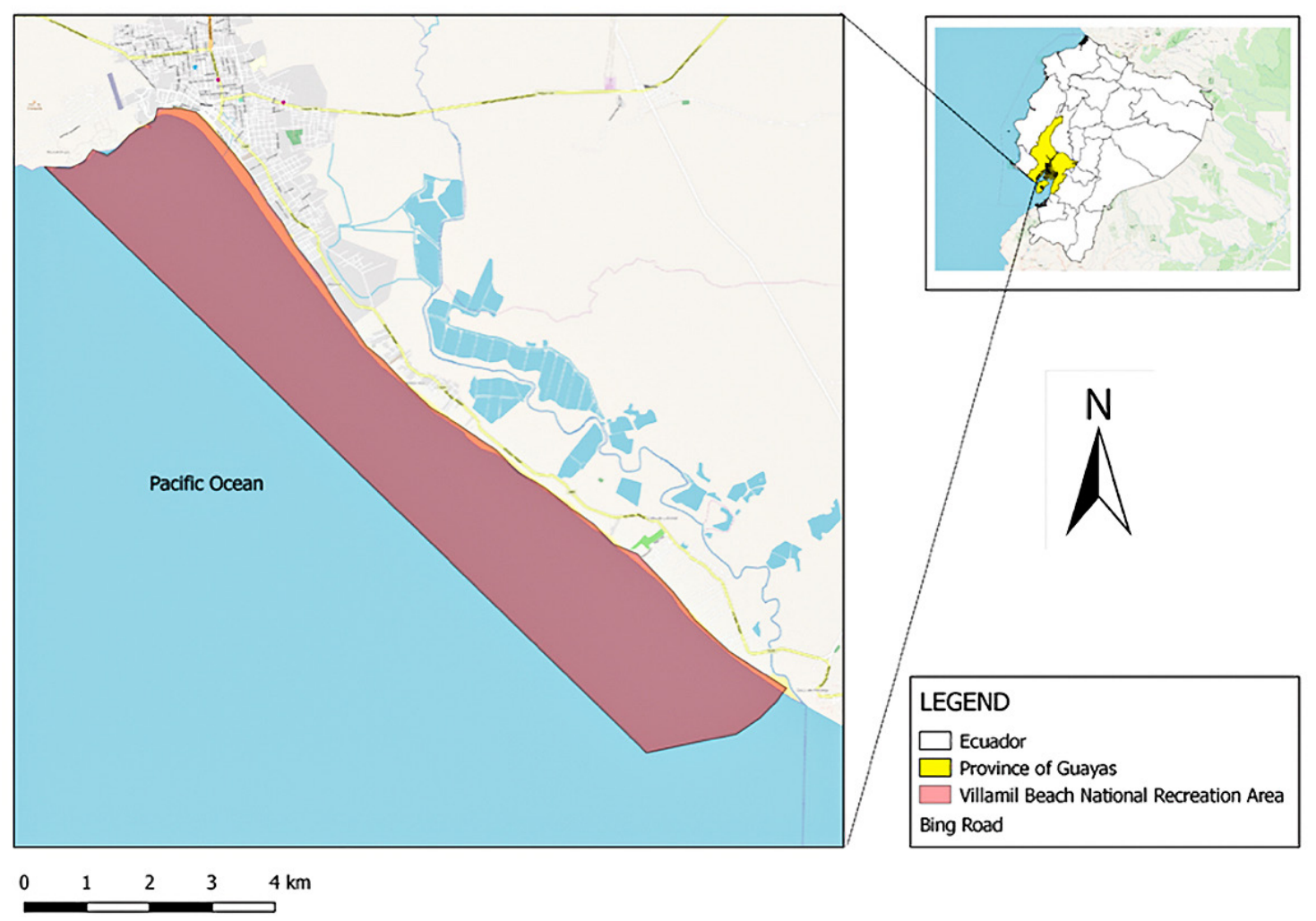

Figure 1. Location of Villamil Beach National Recreation Area VBNRA (Guayas-Ecuador) Source: Prepared by the authors

tional boats 6 meters long by 1 wide), can still be seen and, at festivals rafters use them for artisanal fishing. The activity is considered an icon of cultural identity because it pays homage to the ancestral practices of navigation of the Huancavilca. In 2015, it was declared an Intangible Cultural Heritage of the State (Figure 1).
The area has other tourist attractions such as the sanctuary of the Virgen de las Rocas, Punta el Pelado, San Antonio and Puerto Engabao, where the most ambitious real estate project is built on the seafront. International tourists arrive through the airport of José Joaquín de Olmedo, located about $90 \mathrm{~km}$ from VBNRA.

\section{Methodology}

The present empirical research work was carried out by administering a questionnaire based on previous studies such as those of (Moscardo et al. 2001;Garcia \& Gallard, 2002; Gonzales \& Molina, 2007; Prebensen et al., 2010; Ferreira et al., 2010; Onofri \& Nunes, 2013; Lee., 2018), which include segmentation studies of tourism demand in sun and beach destinations. The field work was carryied out in VBNRA during October and November 2017, the surveys being conducted on Saturdays and Sundays. The questionnaire contained 13 questions aimed at national and foreign tourists, divided into 2 sections, the first aimed at collecting sociodemographic information from tourists, the second focused on demand segmentation. The questions used a variety of techniques including multiple choice questions, closed and Likert scale, with a margin of error of $\pm 4.7 \%$ set to obtain reliable results. To validate the questionnaire, a pilot study of 30 sur- veys was conducted during a single day at the destination.

The information collected was analysed and tabulated using SPSS Version 22 program. Statistical tools such as Chi Square and Spearman Correlations were used to obtain valid results. In this study, Cronbach's alpha was applied to estimate the authenticity of ANOVA responses and statistical procedures. (Table 1)

Table 1. Research file.

\begin{tabular}{|l|l|}
\hline Population & National and foreign visitors \\
\hline Geographic Area & VBNRA, Ecuador \\
\hline Period of realization & October and November, 2017 \\
\hline Process & Simple random sampling \\
\hline Confidence level & $95 \%$ \\
\hline Error range & $\pm 4.7 \%$ \\
\hline Valid questionnaires & 436 \\
\hline
\end{tabular}




\section{Results and Discussion}

\section{Factor Analysis}

A factor analysis allowed us to extract two motivational dimensions. Analysis of the principal component was used as a technique used for data reduction. The varimax rotation method was used to obtain a clearer interpretation of the factors, so that each one had loads of very high or low factors. Using the Kaiser criterion, whereby factors with eingenvalues less than 1.00 are dropped, left us with a two factors solution representing $47.96 \%$ of the total variance. The KMO (Kaiser-Meyer-Olkin) index is 0.8 , so it is acceptable to perform the factor analysis. In addition, Bartlett's sphericity test is significant at the $5 \%$ level, so the factor analysis would be expected to be useful. Results are shown in Table 2.

Table 2. Factor Analysis

\begin{tabular}{|c|c|c|c|}
\hline \multirow{2}{*}{ Variables } & \multicolumn{2}{|c|}{ Component } & \multirow{2}{*}{ Factors } \\
\hline & 1 & 2 & \\
\hline To visit communities & 0.766 & & \multirow{6}{*}{ 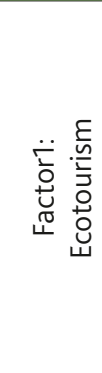 } \\
\hline To practice water sports & 0.712 & & \\
\hline For its nightlife & 0.667 & & \\
\hline To visit family and friends & 0.651 & & \\
\hline $\begin{array}{l}\text { For knowing its flora and } \\
\text { fauna }\end{array}$ & 0.622 & & \\
\hline $\begin{array}{l}\text { For the prices of tourist } \\
\text { services }\end{array}$ & 0.558 & & \\
\hline For resting & & 0.717 & \multirow{4}{*}{ 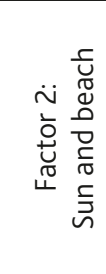 } \\
\hline $\begin{array}{l}\text { For enjoying the sun and the } \\
\text { beach }\end{array}$ & & 0.702 & \\
\hline $\begin{array}{l}\text { To enjoy the typical } \\
\text { gastronomy }\end{array}$ & & 0.694 & \\
\hline For its tourist attractions & & 0.564 & \\
\hline Auto values & 3.171 & 1.624 & \\
\hline$\%$ of variance explained & 31.714 & 16.244 & \\
\hline$\%$ of cumulative variance & 31.714 & 47.958 & \\
\hline $\mathrm{KMO}$ & 0.8 & & \\
\hline Bartlett's sphericity test & \multicolumn{2}{|c|}{$\begin{array}{c}\text { Chi squared } \\
874.475 \text { sig< }<0.001\end{array}$} & \\
\hline
\end{tabular}

Extraction method: Analysis of main components.

Method of rotation: Varimax with Kaiser.

According to the results of Table 2, the factor with the greatest explanatory capacity, labelled "Ecotourism", accounts for $31.71 \%$ of the total variance. This first dimension is related to motivations for visiting communities, for performing water sports, for nightlife, for visiting relatives, and for flora and fauna. The second factor is labelled "Sun and beach" and accounts for another $16.24 \%$ of the total variance. This second dimension is related to tourists who are moti- vated by resting, enjoying the sun and the beach, the typical cuisine and tourist attractions.

\section{Segmentation in coastal marine destinations}

To this end, a non-hierarchical K-means cluster analysis was carried out. Under the criterion of maximizing the variance between typologies, and minimizing the variance within each typology, the best solution meeting the criteria established three clusters. The characterization of the clusters from the means of the motivation variables is shown in Table 3. The F statistic of the ANOVA allows us to conclude that the means compared are not equal, but it does not allow us to specify where the differences are. To ascertain which means differs from the others, post hoc multiple comparisons have been used. In making these comparisons, it cannot be assumed that the population variances are equal. The F statistic of the ANOVA is based on the fulfilment of the assumptions of normality and homoscedasticity. Given that it is not possible to assume that the population variances are equal, because the critical level associated with the Levene statistic is less than 0.05, the Brown-Forsythe and Welch statistics are used as an alternative to the ANOVA F statistic. Since the critical level associated with both statistics is less than 0.05 one may reject the hypothesis of equality of means and conclude that the averages of the motivational variables of the three comparative groups are not equal. To contrast the significant differences between the different means, the GamesHowell test has been applied.

Table 3. Characterization of the cluster based on the motivational variable

\begin{tabular}{|l|c|c|c|}
\hline \multirow{2}{*}{ Motivational variables } & \multicolumn{3}{|c|}{ Cluster } \\
\cline { 2 - 4 } & 1 & 2 & 3 \\
\hline For resting & $4.4^{* *}$ & $4.0^{* *}$ & $2.8^{* *}$ \\
\hline For enjoying the sun and the beach & 4.5 & 4.4 & $3.0^{* *}$ \\
\hline To practice water sports & 1.7 & $3.8^{* *}$ & 1.6 \\
\hline To visit family and friends & $1.6^{* *}$ & $4.0^{* *}$ & $2.0^{* *}$ \\
\hline To enjoy the typical gastronomy & 4.5 & 4.6 & $3.2^{* *}$ \\
\hline For its tourist attractions & 4.0 & 4.3 & $2.4^{* *}$ \\
\hline For its nightlife & 2.1 & $3.5^{* *}$ & 1.8 \\
\hline For the prices of tourist services & $2.8^{* *}$ & $3.9^{* *}$ & $1.9^{* *}$ \\
\hline To visit communities & $1.5^{* *}$ & $3.7^{* *}$ & $1.9^{* *}$ \\
\hline For knowing its flora and fauna. & $2.4^{* *}$ & $4.1^{* *}$ & $2.0^{* *}$ \\
\hline
\end{tabular}

** Bold values show significant differences with at least two of the means of the three clusters.

As shown in Table 3, in the first group are tourists who have high motivation for enjoying the sun and 
the beach (4.5), for the typical gastronomy (4.5) and for the rest (4.4), the members of this group are labelled "Beach lovers" and are also related to the motivational dimension sun and beach. The second group is formed by visitors who have high motivation for enjoying the typical gastronomy (4.6), by the sun and the beach (4.4), for the tourist attractions (4.3) and for knowing the flora and fauna (4.1) - these tourists are labelled "Coastal Nature" and are related to the motivational dimension ecotourism. The third group are tourists who have medium and low motivation in all aspects, a group labelled "Coastal Passive" which is not related to any of the two dimensions found.

\section{Relationship of satisfaction with the segments found}

In order to better understand the relationship of the three groups with satisfaction, a chi-square significance contrast has been made to determine if satisfaction is a variable that is really relevant to the analysis. The results are shown in Table 4.

The results of Table 4 show statistically significant differences between the three groups in terms of satisfaction $\left(\chi^{2}=40.484, p<0.001\right)$. "Coastal Nature", have the highest levels of satisfaction, followed by "Beach lovers". The "Coastal Passive", are those with the low- est levels of satisfaction. In addition, the "Coastal Nature" are the group with the highest percentage of tourists very satisfied in relation to the others (Figure 2).

The segments are summarized as follows:

- Cluster 1. (Beach lovers - $45.74 \%$ of the sample)

They have high motivations for enjoying the sun and the beach (4.5), for the typical gastronomy (4.5) and for resting (4.4). In addition, they are related to the motivational dimension sun and beach, and have a lower level of satisfaction in relation to the "Coastal Nature", and higher in relation to the "Coastal Passive".

- Cluster 2. (Coastal Nature - $25.51 \%$ of the sample) They have high motivations for enjoying the typical gastronomy (4.6), for the sun and the beach (4.4), for the tourist attractions (4.3) and for knowing the flora and fauna (4.1). They are also related to the ecotourism motivational dimension and have a higher level of satisfaction in relation to the other groups.

- Cluster 3. (Coastal Passive - $\mathbf{2 8 . 6 3 \%}$ of the sample) They have medium and low motivations in all aspects. In addition, they are not related to any of the two dimensions found and have the lowest level of satisfaction in relation to the other groups.

Table 4. Cluster relationship with satisfaction

\begin{tabular}{|c|c|c|c|c|c|c|}
\hline \multirow{2}{*}{$\begin{array}{l}\text { General } \\
\text { Satisfaction }\end{array}$} & \multicolumn{3}{|c|}{ Number of cluster cases } & \multirow{2}{*}{ Total } & \multirow{2}{*}{ Coefficient } & \multirow{2}{*}{ sig. } \\
\hline & 1 & 2 & 3 & & & \\
\hline Very Unsatisfied & & $1.8 \%$ & $2.4 \%$ & $1.1 \%$ & \multirow{5}{*}{40.484} & \multirow{5}{*}{$<0.001$} \\
\hline Little Satisfied & $1.5 \%$ & & $3.2 \%$ & $1.6 \%$ & & \\
\hline Partially satisfied & $16.1 \%$ & $9.9 \%$ & $31.2 \%$ & $18.9 \%$ & & \\
\hline Satisfied & $56.8 \%$ & $48.6 \%$ & $49.6 \%$ & $52.6 \%$ & & \\
\hline Very satisfied & $25.6 \%$ & $39.6 \%$ & $13.6 \%$ & $25.7 \%$ & & \\
\hline Total & $100.0 \%$ & $100.0 \%$ & $100.0 \%$ & $100.0 \%$ & & \\
\hline
\end{tabular}

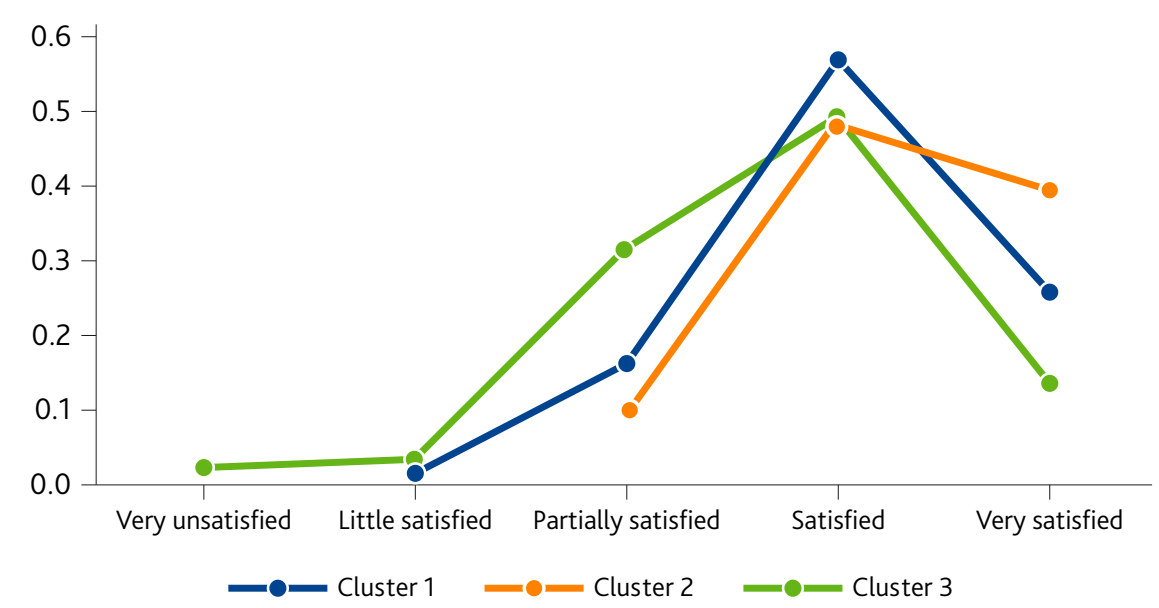

Figure 2. Satisfaction by cluster (in percentages) 


\section{Discussion}

After analysing the theory related to the motivation and satisfaction in destinations with coastal marine characteristics, such as the Villamil Beach National Recreation Area, the results show a relationship with the two dimensions of motivation found by Prebensen, Skallerud, and Chen (2010): "Body-related" is similar to the dimension of "sun and beach" of the present study and "Mind- related" similar to "Ecotourism" of the present study, which would seem to show that in these destinations with natural and cultural characteristics one could find the two dimensions indicated. Regarding the motivations in coastal marine destinations, the dimensions found in the present study (Sun $\&$ beach, and Ecotourism) are similar (Kruger \& Saayman, 2010, Van Der Merwe et al., 2011)

From the theoretical perspective, our results are similar to those found in previous research on demand segmentation. For example, Moscardo et al. (2001) found three segments: Eco-coastal, which is a group similar to the "Coastal Nature". Their Active beach tourist is analogous to "Beach lovers", while the group Passive Seaside, and is similar to the "Coastal Passive" segment of the present investigation. On the other hand, Onofri and Nunes (2013) find two segments of tourists: their "Greens" are similar to our "Coastal Nature" and both our "Beach lovers" are similar. Our findings show the existence of a third segment, the "Coastal Passive". Comparing our results with the study by Valls et al. (2018), their Visiting and the Enjoying are similar to our "Coastal Nature". Their Holidaying is not found, while their Beaching and Relaxing are similar to our "Beach lovers". On the other hand, Carvache-Franco et al., 2019 propose four segments for the demand of foreign tourists in coastal marine destinations: Eco-coastal, is similar to the "Coastal Nature"; Indifferent is similar to the "Coastal Passive" while Water Sports and Sun and Beach" are similar to our "Beach lovers".

\section{Conclusions}

The segmentation of demand in a coastal marine destination within a national recreation area provides important information that allows the creation of products related to the clusters found. In this study, two motivational dimensions were found. The first is the dimension "Ecotourism" related to the motivations for visiting the communities, for performing water sports, for nightlife, for visiting relatives, and for flora and fauna. The second is the dimension "Sun and beach", related to the motivations for resting, for enjoying the sun and the beach, for the typical gastronomy and for the tourist attractions. The existence of two dimensions is mentioned in Prebensen et al. (2010) and their "Body-related" is similar to our "Sun and beach" dimension, while their "Mind-related" is similar to the "Ecotourism" of the present study. Also, the motivations in coastal marine destinations found in the present study: Sun \& beach, and Ecotourism, are similar to those in (Kruger \& Saayman, 2010, Van Der Merwe et al., 2011). We concluded that the Villamil Beach National Recreation Area is a destination with coastal marine characteristics (Orams \& Lück, 2016).

On the other hand, three segments of tourists were found. The first segment is formed by the "Beach lovers", who have high motivations for enjoying the sun and the beach, for the typical gastronomy and for resting. In addition, they have a lower satisfaction in relation to the "Coastal Nature", and greater in relation to the "Coastal Passive". The second segment is formed by the "Coastal Nature", who have high motivation for enjoying the typical gastronomy, for the sun and the beach, for the tourist attractions, and for knowing the flora and fauna. In addition, this is the segment that presents the highest level of satisfaction in relation to the other groups. The third segment is formed by the "Coastal Passive", who have medium and low motivations in all aspects and who have the lowest level of satisfaction in relation to the other groups. Differences have been found between the three groups in terms of satisfaction, "Coastal Nature", have the highest levels of satisfaction, followed by "Beach lovers". The "Coastal Passive", are those with the lowest levels of satisfaction. In addition, the "Coastal Nature" are the group with the highest percentage of tourists very satisfied in relation to the others. The findings show that the motivational dimension "ecotourism" is an important variable for tourists in a coastal marine destination.

As for theoretical implications, it has been found that the present study's two groups are similar to those of Onofri and Nunes (2013) who found two segments "Greens" are similar to the "Coastal Nature" of the present study "Beach lovers" are similar to "Beach lovers" of this study. The contributes to the scientific literature with a third group, the "Coastal Passive". On the other hand, the study suggests three clusters: "Beach lovers", "Coastal Nature", and "Coastal Passive", that are similar to those found (Moscardo et al., 2001; On- 
ofri \& Nunes, 2013, Valls et al., 2018; Carvache-Franco et al., 2019). The empirical evidence is that, in this type of destination, there are different groups of tourists with different aspects of satisfaction. The results have practical implications, the findings help tourism service providers understand the characteristics of each group and produce products tailored to their demands. Finally, the main limitation of the present study is the relatively short time frame in which it was carried out. As a future line of research, a study could be carried out on the characteristics of each cluster, based on environmental awareness, to develop conservation strategies aimed at a coastal marine destination.

\section{References}

Beatley, T., Brower, D.J., \& Schwab, A.K. (2002). An Introduction to Coastal Zone Management. Washington, DC: Island Press.

Bigné Alcañiz, E., Sánchez García, I., \& Currás Pérez, R. (2007). El papel de la imagen del destino en la valoración y comportamiento postcompra del turista de sol y playa. Papers de Turisme, 42(4), 5773. Available at: https://doi.org/10.108o/14616688.20 15.1093538

Carvache-Franco, M., Carvache-Franco, W., Macas, C., \& Orden, M. (2018). Motivaciones, Valoración y Satisfacción del Turista en un destino de Sol y Playa de Ecuador. Revista Espacios. 39(13), 4-16

Carvache-Franco, W., Carvache-Franco, M., Carvache-Franco, O., \& Hernández-Lara, A. B. (2019). Segmentation of foreign tourist demand in a coastal marine destination: The case of Montañita, Ecuador. Ocean \& Coastal Management, 167, 236-244. Available at: https://doi.org/10.1016/j.ocecoaman.2018.10.035

De Nisco, A., Mainolfi, G., Marino, V., \& Napolitano, M. R. (2015). Tourism satisfaction effect on general country image, destination image, and post-visit intentions. Journal of Vacation Marketing, 21(4), 305-317. Available at: https://doi. org/10.1177\%2F1356766715577502

Ferreira Lopes, S. D., Rial Boubeta, A., \& Varela Mallou, J. (2010). Segmentación post hoc del mercado turístico español: Aplicación del análisis cluster en dos etapas. Estudios y perspectivas en turismo, 19(5), 592-606.

Garcia, C. R., \& Gallard, G. C. (2002). Segmentación del mercado turístico según las preferencias ambientales. Cuadernos de Turismo, (9), 123-136.

González, P. R., \& Molina, Ó. M. (2007). La segmentación de la demanda turística española. Metodología de encuestas, 9(1), 57-92.

Ho, G. T., Ip, W. H., Lee, C. K. M., \& Mou, W. L. (2012). Customer grouping for better resources allocation using GA based clustering technique. Expert Systems with Applications, 39(2), 1979-1987. Available at: https://doi.org/10.1016/j.eswa.2011.08.045

ITB. (2018). ITB World Travel Trends Report 2017/2018. Available at: https:/www.itb-berlin.de/media/itb/
itb_dl_all/itb_presse_all/ITB_WTTR_A4_2018_ interaktiv.pdf

International Coastal and Marine Tourism Society (2013). What is Coastal and Marine Tourism? Available at: www.coastalmarinetourism.org/whatis-cmt.html.

Kruger, M., \& Saayman, M. (2010). Travel motivation of tourists to Kruger and Tsitsikamma National Parks: A comparative study. South African Journal of Wildlife Research-24-month delayed open access, 40(1), 93-102. Available at: https://hdl.handle. net/10520/EJC117327

Lee, T. H., Jan, F. H., Tseng, C. H., \& Lin, Y. F. (2018). Segmentation by recreation experience in islandbased tourism: A case study of Taiwan's Liuqiu Island. Journal of Sustainable Tourism, 26(3), 362-378. Available at: https://doi.org/10.1080/09669582.2017.1 354865

Lück, M. (2007). Nautical tourism: concepts and issues. New York: Cognizant Communication Corporation.

Martínez, R. (2001). Aproximación al estudio del sector turístico almeriense: análisis de la oferta y la demanda en temporada alta. Cuadernos de Turismo, (7), 81-92.

Middleton, V. T., Fyall, A., Morgan, M., \& Ranchhod, A. (2009). Marketing in travel and tourism. Routledge.

Ministry of Environment MAE, (2012). http://www. ambiente.gob.ec. Available at: http:/guayaquil. gob.ec/Dragado/1)\%2oPROYECTO\%2oAPP\%20 DRAGADO/b)\%20CAPI\%CC\%81T ULO \% 20 $1 \% 2$ OPRESENTACIO \% CC\% 81 N\% 20 DEL $\% 20$ PROYECTO/c)\%2oanexos/Anexo\%2012.-\%2oPlayas\%2ode\%2oVillamil.pdf

Ministry of Environment MAE, (2015). Más de 100000 turistas visitaron las áreas protegidas.Available at: http://www.ambiente.gob.ec/mas-de-10o-ooo-turistas-visitaron-las-areasprotegidas/

Ministry of Environment MAE, (2017). Sistema Nacional de Areas Protegidas del Ecuador.Available at: http:// areasprotegidas.ambiente.gob. ec/es/areas-protegidas/\% $\mathrm{C}_{3} \%$ A 1 rea-nacionalderecreaci\% $\mathrm{C}_{3} \% \mathrm{~B}_{3}$-playas-de-villamil. 
Ministry of Tourism MINTUR (2018). Quito, Ecuador., Indicadores OMT-CEPAL, https://www.turismo.gob.ec/. Available at: https://www.turismo. gob.ec/:https://servicios.turismo.gob.ec/index.php/ portfolio/turismo-cifras/18-analisis-economico/ indicadores-omt-cepal/96

Molera, L., \& Albaladejo, I. P. (2007). Profiling segments of tourists in rural areas of South-Eastern Spain. Tourism management, 28(3), 757-767. https:// doi.org/10.1016/j.tourman.2006.05.006

Morante, A. G., García, I. S., \& Blas, S. S. (2007). Caracterización del turista de sol y playa: una comparativa con el turista rural y cultural. In Turismo en los espacios litorales: sol, playa y turismo residencial $/ 9^{\circ}$ Congreso de Turismo, Universidad y Empresa (pp. 105-121).

Moscardo, G. (2000). Understanding wildlife tourism market segments: An Australian marine study. $\mathrm{Hu}$ man Dimensions of Wildlife, 5(2), 36-53. https://doi. org/10.1080/10871200009359178

Onofri, L., \& Nunes, P. A. (2013). Beach 'lovers' and 'greens': A worldwide empirical analysis of coastal tourism. Ecological Economics, 88, 49-56. Available at: https://doi.org/10.1016/j.ecolecon.2013.01.003

Orams, M. (1999). Marine Tourism. Development, Im-pacts and Management. London \& New York: Routledge

Orams, M. B., \& Lück, M. (2013). Marine systems and tourism. In Holden, A. \& D. Fennell (eds.), The Routledge Handbook of Tourism and the Natural Environment. London: Routledge, 170-182.

Orams M., Lueck M. (2016) Coastal tourism. In Jafari J. \& Xiao H. (eds), Encyclopedia of Tourism. Cham: Springer, 157-158.

Pesonen, J. A. (2012). Segmentation of rural tourists: Combining push and pull motivations. Tourism and Hospitality Management, 18(1), 69-82. Available at: https://hrcak.srce.hr/83824

Prebensen, N., Skallerud, K., \& Chen, J. S. (2010). Tourist motivation with sun and sand destinations: satisfaction and the wom-effect. Journal of Travel \& Tourism Marketing, 27(8), 858-873. Available at: https://doi.org/10.1080/10548408.2010.527253
Pulido-Fernández, J. I., \& Sánchez-Rivero, M. (2010). Attitudes of the cultural tourist: A latent segmentation approach. Journal of Cultural Economics, 34(2), 111-129. Available at: https://doi.org/10.1007/ S10824-010-91151

Rivas, J. (2004): Estructura y Economía del Mercado Turístico. Septem Ediciones, Oviedo.

Saayman, M., Slabbert, E., \& Van Der Merwe, P. (2009). Travel motivation: a tale of two marine destinations in South Africa. South African Journal for Research in Sport, Physical Education and Recreation, 31(1), 81-94. Available at: https://hdl.handle. net/10520/EJC108889

Srihadi, T. F., Sukandar, D., \& Soehadi, A. W. (2016). Segmentation of the tourism market for Jakarta: Classification of foreign visitors' lifestyle typologies. Tourism Management Perspectives, 19, 32-39. Available at: https://doi.org/10.1016/j.tmp.2016.03.005

Territorial Development and Planning Plan Playas Villamil, 2014 - 2022. Clima de Playas. Available at: http://app.sni.gob.ec/sni/link/sni/ PORTAL_SNI/data_sigad_plus/sigadplusdiagnostico/o960005530001_DIAGN\%C3\%93STICO_FINAL_PLAYAS_12-03-2015_22-09-38.pdf

UNWTO World Tourism Barometer Advance Release. OMT, (2018). http://mkt.unwto.org/barometer. Available at: http://mkt.unwto.org/barometer: http://cf.cdn.unwto.org/sites/all/files/pdf/unwto_ barom18_o1_january_excerpt_hr.pdf

Valls, A., Gibert, K., Orellana, A., \& Antón-Clavé, S. (2018). Using ontology-based clustering to understand the push and pull factors for British tourists visiting a Mediterranean coastal destination. Information \& Management, 55(2), 145-159. https://doi. org/10.1016/j.im.2017.05.002

Van der Merwe, P., Slabbert, E., \& Saayman, M. (2011). Travel motivations of tourists to selected marine destinations. International journal of tourism research, 13(5), 457-467. Available at: https://doi. org/10.1002/jtr.820

Woodside, A. G., \& Martin, D. (Eds.). (2008). Tourism management: analysis, behaviour and strategy. Cambridge: Cabi. 